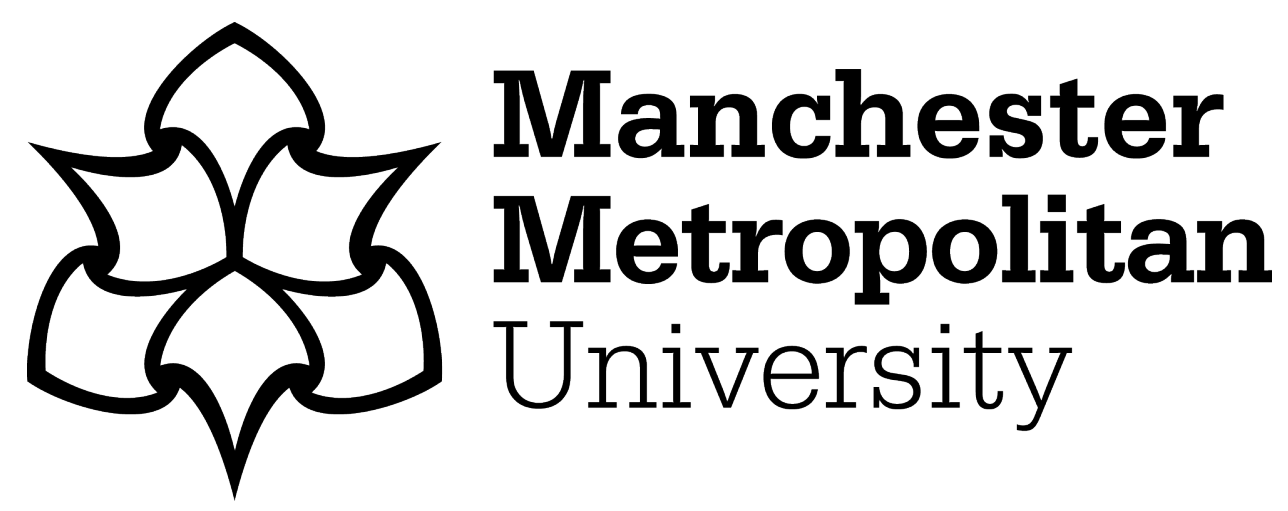

Malin, Stephanie A and Alexis-Martin, Becky (2020) Embedding the atom: pro-neoliberal activism, Polanyi, and sites of acceptance in American uranium communities. The Extractive Industries and Society, 7 (2). pp. 535-543. ISSN 2214-790X

Downloaded from: https://e-space.mmu.ac.uk/623656/

Version: Accepted Version

Publisher: Elsevier BV

DOI: https://doi.org/10.1016/j.exis.2018.12.004

Usage rights: Creative Commons: Attribution-Noncommercial-No Derivative Works 4.0

Please cite the published version 
Original article

\title{
Embedding the atom: Pro-neoliberal activism, Polanyi, and sites of acceptance in American uranium communities ${ }^{\text {th }}$
}

\author{
Stephanie A. Malin ${ }^{\mathrm{a}, *}$, Becky Alexis-Martin ${ }^{\mathrm{b}}$ \\ ${ }^{a}$ B234 Clark Building, Department of Sociology, Colorado State University, Fort Collins, CO, 80523-1784, United States \\ ${ }^{\mathrm{b}}$ Manchester Metropolitan University, United States
}

\section{A R T I C L E I N F O}

\section{Keywords:}

Uranium

Environmental justice

Polanyi

Double movement

Pro-neoliberal activism

\begin{abstract}
A B S T R A C T
In North America, uranium workers are fighting for their right to participate in a free-market system that provides them with small personal benefits. These workers experience powerlessness, instability, and unpredictability - or social dislocation - by living amidst capitalism's polluted ecosystems, unstable economies, and disintegrating communities. However, they feel reliant on uranium for their livelihoods and strongly support the industry's renewal and form sites of acceptance to support industry renewal. Here, we explore the phenomenon of pro-neoliberal activism emerging in communities that identify with uranium markets and that trust in corporate self-regulation, private transparency, and the perceived benefits of potential economic development. Polanyian theory helps us analyze these curious socio-environmental outcomes. While social movements might be 'progressive,' 'regressive,' or otherwise diverge, Polanyi consistently characterized double movement activists as protecting communities and ecosystems from unstable, self-regulating market systems. But here we see something different and ask: First, how does pro-neoliberal activism contribute to the embedding and institutionalization of neoliberal regimes in uranium mining communities? Second, what structural mechanisms precede and help to facilitate socio-cultural support for free markets and corporate self-regulation, as opposed to support for reembedding markets in local, public social protections for the US uranium industry?
\end{abstract}

\section{Introduction}

In North America, uranium workers are fighting for their right to participate in a free market system that provides them with small personal benefits, despite global environmental and social costs. These workers experience powerlessness, instability, and unpredictability - or social dislocation - by living amidst capitalism's polluted ecosystems, unstable economies, and disintegrating communities (Stanfield 1989). However, they feel reliant on uranium for their livelihoods, despite the sector's prioritization of the free market above socio-environmental protections (Brenner, Peck, and Theodore 2010; Castree, 2008a, 2008b; McCarthy, 2005a, 2005b). For many uranium communities, their collective trust in corporate self-regulation and transparency has led to internal mobilization and pro-neoliberal activism to retain what little protection that the sector offers compared to the diminishing American welfare state. This mobilization occurs out of individual necessity and faith in the free market. The welfare state safety net is inadequate, there is a yawning pay inequality gap, and a "remoralization of the poor", whereby economic participation is perceived as individual trouble rather than state issue. This incentivizes workers to retain their employment in any possible way (Castree, 2010: 11). Uranium workers have experienced hardship from the decline of the industry in recent decades. However, the resurgence of Republican conservatism is influencing the uranium industry in unanticipated ways as national protectionism, expansion, and deregulation return to the political agenda. Since becoming president in 2016, President Donald Trump has begun to unshackle American industry and free-market economy through trade tariffs, and has started to renegotiate the North American Free Trade Agreement to prioritize US interests (US Government, 2017). Trump is also changing the nature of Obama-era public socio-environmental protections, by reducing and relaxing social and environmental policies. His actions already affect the uranium industry, as he attempts to overturn uranium mining bans in the Grand Canyon and open public lands, such as Bears Ears National Monument, to industry. This is due to pro-neoliberal pressure, and may increase job security for uranium industry workers at a socio-environmental cost. We know that environment, society, and economy are entangled alongside the uranium industry, from anti-nuclear activism to worker exploitation. However, the

\footnotetext{
Portions of the chapter, particularly interview excerpts, have been published in The Price of Nuclear Power: Uranium communities and environmental justice (2015).

* Corresponding author.

E-mail address: stephanie.malin@colostate.edu (S.A. Malin).
} 
perception of environmental degradation due to the activities of the free-market economy is not new. Polanyi pioneered links between environment and economy in "The Great Transformation" (Polanyi, 1944). For Polanyi, the Industrial Revolution created fundamental shifts in human relations, communities, and societal relationships to land use and the environment, aided and emphasized by increasingly market-based, disembedded systems of capitalism (Polanyi, 1944 (2001), 1977; Block, 2008). His theory of market society was pioneering, as it recognized and deconstructed the 'self-regulating' economic market as an historical anomaly, detached and disembedded from environmental consequences. Polanyi observed that capitalist modes of production disrupted daily life, with negative impacts to the fabric of society, because market-based economies introduce fundamentally different social relations. Thick reciprocity weakens and "communities succumb" as "human society becomes an accessory of the economic process" (2001:79). Polanyi described how “...no society could live for any length of time unless it possessed an economy of some sort; but previous to our time no economy has existed that, even in principle, was controlled by markets...Such an institutional pattern could not function unless society was somehow subordinated to its requirements" (2001: 71). Rampant social dislocations ${ }^{1}$ result, and double movements gradually mobilize increased social protections - including state-supported labor and environmental regulations. Polanyi anticipated that the harmful consequences of capitalism would not be unequivocally accepted by industrial communities. Social mobilization has occurred, as movements formed to counteract the dehumanizing and unsustainable consequences of laissez-faire development, in what Polanyi termed 'the double movement' (Dale, 2012). Polanyian theory has thus resurfaced as a popular tool for scholars to examine how the processes of neoliberalization, and the process of governance through global deregulation, have impacted upon political-economic and social systems (Hejeebu and McCloskey, 1999, Tarrow, 2005, Block, 2008, Watkins, 2015). Though neoliberalism materializes in starkly different ways, its multiple forms align in privileging: de- and re-regulation, the privatization of natural resources and public goods, individualization and individualized agents of social change, and the prioritization of free markets above socio-environmental protections (Brenner, Peck, and Theodore 2010; Castree, 2008a, 2008b). Polanyi observed that double movements re-embed capitalist economic markets in their socio-environmental contexts by the reinterpretation of capitalism within a framework of more positive socio-environmental contexts and better worker protection. Typically, double movement activism has targeted the state to create and enforce regulations for the protection of people, communities, and environments. Whilst such movements might be 'progressive,' 'regressive,' or otherwise diverge in their political persuasions, Polanyi consistently characterized double movement activists as protecting communities and ecosystems from unstable, self-regulating market systems. Here, we explore the phenomenon of pro-neoliberal activism that creates sites of acceptance in uranium mining communities. These communities identify with uranium markets, and trust in corporate self-regulation, private transparency, and the perceived benefits of potential economic development. We examine the U.S. uranium industry - its historical neoliberalization, its current revitalization, and the strong pro-neoliberal support that has organically mobilized to fight for the expansion of uranium production, despite the industry's global and disembedded nature. Pro-neoliberal activists are influenced by hegemonic neoliberal values; in some cases, activists see disembedded markets as vitally tied to the social fabric of their communities. The questions we ask have become pertinent as America becomes more conservative. First, how does pro-neoliberal activism contribute to the embedding and institutionalization of neoliberal

\footnotetext{
${ }^{1}$ Herein, social dislocation refers to persistent feelings of stress, instability, vulnerability, and/or perceived powerlessness in the context of free market capitalist modes of production and exchange.
}

regimes in uranium mining communities? Second, what structural mechanisms precede and help facilitate socio-cultural support for free markets and corporate self-regulation, as opposed to support for reembedding markets in local, public social protections of the U.S. uranium industry? In this paper, we analyze four mechanisms of neoliberalis - marketization, privatization, federal de-regulation and marketfriendly re-regulation, and devolution - and their roles in shaping activism responding to revitalized uranium production in the U.S. We interrogate historical and structural mechanisms that have helped nurture pro-neoliberal activism, where social movement organizations support renewed uranium production. The following analysis is the product of on-going, in-depth fieldwork and data collection that began in 2006. The first author has conducted 75 in-depth interviews, a four-community survey regarding uranium's legacy and renewal in the region, archival analyses of newspapers and state and federal regulatory frameworks, and participant observation in multiple uranium communities across the Four Corners region. Using these data, we have identified and described the conditions under which people mobilize pro-neoliberal activism and form sites of acceptance, in communities where (uranium) markets are perceived as integral to local social fabrics, offering a neoliberal application of Polanyi's double movement theory.

\section{Toward a theory on pro-neoliberal activism: polanyian double movements and neoliberalism}

Neoliberalism manifests in three ways, including: philosophies of free market superiority; policy discourses lauding market-friendly state deand re-regulation and self-governing individuals; and policy measures that structure free trade agreements and often devolve governance to states and localities (Castree, 2010). Various forms of neoliberal ideology and policy have become prominent since the 1980s (Harvey, 2005). During this time, neoliberal ideology began to dominate global policy and development strategies, helping disembed economic activities from socio-environmental contexts internationally (Benería 1999). Elite social classes mobilized behind this transition, and neoliberalism became less visible and more hegemonic over time (Foucault, 2008; Harvey, 2005), shaping policies of influential organizations including the International Monetary Fund and World Bank (Goldman 2005). Neoliberal theory proposes that self-regulating markets provide the most efficient, profitable form of economic and social organization - if left to function without state interference (Konings, 2012; Harvey, 2005). Markets are seen as mechanisms by which human shortcomings, emotions, and inequalities disappear as markets behave rationally, respond to clear price signals across cultural and national contexts, and allow unlimited expansion. However, self-regulating markets remain utopian fictions for two reasons. First, the state must create and protect spaces for commodity markets to thrive. Market-based societies therefore rely on states that, at minimum, can regulate and enforce systems of private property laws. Some would also argue that the state must protect the Public Trust, stewarding and preserving the integrity of natural resources like air and water for future generations (Gauchat, 2012). Second, contemporary market systems rely on fictitious commodities; land, labor, and money facilitate free trade. Their commodification is inherently de-stabilizing because they are not produced by people for trade, are unpredictable, and are not amenable to marketization (Polanyi, 1944). Furthermore, neoliberal ideologies are socially harmful, exacerbating social stratifications. Sharp increases in economic inequality represent just one significant social cost. People mobilize in neoliberalizing contexts because market-centered policies create "a yawning gap between rich and poor, financial crises galore, and growing pressure on the natural environment" (Dale, 2010:215). The onus is placed upon the individual to thrive, despite stratified and difficult socio-economic conditions, which creates a highly individualistic society with poor support for the "undeserving poor" (Katz, 1989). This culture has been amplified by Trump's presidency, marking an end of an era of progressive neoliberalism and the rise of 
nationalist populism steeped in support for economic development at all costs (Fraser, 2017). Importantly, while Trump's anti-free trade rhetoric does not map on to neoliberal ideology, his stronger political maneuvers to encourage industry-friendly deregulation and privatization of public goods have emphasized two other central components of neoliberal ideology. This analysis helps understand why members of the public also support this view and see it as aligned with their interests. There are four central mechanisms of neoliberalization that foster contemporary pro-neoliberal activism, including: marketization, privatization, federal de-regulation, and market-friendly re-regulation/ devolution. These mechanisms help shape political-economic contexts that have normalized neoliberal policy and ideology in the U.S. for decades. Marketization is the commodification of communally-owned natural resources or goods. Privatization refers to the creation of private markets for property, whereby commonly held resources previously owned by the state, communities, or cooperatives are sold to individual firms. Deregulation occurs when the state reduces regulatory enforcement of social, cultural, or environmental aspects of society, while giving more power to non-state actors like corporations to privately enforce or self-monitor regulatory compliance. Re-regulation complements deregulation, with the state recast as "market manager" (Castree, 2010; McCarthy, 2005a; Mansfield, 2007; Fletcher, 2010) rather than a provider of support for state institutions or citizens. Devolution consists of scaling down governance functions from the federal state to individual states or even communities; devolved governance is often accompanied by decreases in public funding, which lead to reduced capacities to administer social and regulatory enforcement programs at local levels. People and communities begin to internalize and mirror neoliberalized markets, becoming more 'free', atomized, and self-governing as the state retreats (Bourdieu 1998; Harvey, 2005; Castree, 2010). Educational and social policies that promote cultures of individualized 'workfare' illustrate the individualized kinds of policies, rather than collective solutions, pursued under neoliberalization and encourage building one's human capital, even if it requires a lifetime commitment to re-education as market demands shift. State social policy typically offers support only to the most vulnerable in society, leading to a "remoralization of the poor" (Castree, 2010: 11). Of course, the very hegemonic nature of neoliberalism means that many Americans experience false consciousness about their class status and interests in this system, often identifying with the very figures and policies that further undermine democratic action, exacerbate economic inequality, and degrade the environment (with Trump's election and administration providing just one stark example). In this way, people's internalization of neoliberal norms facilitates a Foucaultian outcome, where people monitor their own compliance and conform through their loyalty to free markets, deregulation, and privatization. Scholars can use Polanyi to understand this under-explored type of social activism: pro-neoliberal activism for the retention of industrial deregulation and privatized extraction. Activism of this nature has a significant role in further embedding market-based neoliberal regimes by dis-embedding expectations of public social protections. As the state retreats under neoliberal reregulation, democratic space becomes vital for double movement mobilization. Evidence suggests that mobilization relies on the existence of democratic social space, as pro-capital regimes can monopolize political space and undermine resistance efforts (Silver and Arrighi, 2003; Block, 2008), with their fluid and abundant resources to acquire political-ideological space (Bugra and Agartan, 2007). Proneoliberal mobilization and activism has been neglected by scholars. Polanyi's double movement is regularly treated as a given contemporary outcome rather than a testable hypothesis (McCarthy, 2005b; Castree, 2008a, 2008b) - in part because double movements do indeed persist. For instance, environmental activists have fought water privatization and delivery (Bakker, 2010, 2003; Laurie and Marvin 1999; Loftus and McDonald 200; Prudham, 2004; Perrault 2008; Smith, 2008); the impacts of neoliberal developmentalism (Lim 2014); mining (Peck, 2013; Bury, 2004, 2005; Rodrigues 2003); and environmental injustices related to agriculture (Brown and Getz, 2008; Harrison 2008; Sugden 2009). Importantly, though, progressive movements tend to receive more analytical attention as they fight neoliberalizing processes (eg., Hettne, 1991; Cox, 1994, 1996; Baum 1996; Mittelman 1997; Adaman et al., 2003; Ringmar 2005; Randles, 2007). Thus, some analysts mistakenly interpret corporatist, market-based activism as progressive (see Dale, 2010; Stanfield, 1986) and fail to recognize important divergent strains of activism that further embed and institutionalize neoliberal processes. Polanyian double-movement theory has been applied to U.S. agro-food movements (Guthman, 2008); Australian extraction (Peck, 2013); and global environmental movements and governance (Prudham 2013; Heynen and Perkins, 2005; Heynen and Robbins, 2005; Heynen et al., 2007; McCarthy, 2005a; Peck and Tickell, 2002). Scholars present related activism as progressive, double movement activism, which initiates transformative social changes to counter dis-embedded, market-based, capitalist economies (Guthman 2007; Dale, 2010; Castree, 2010a and b). Even critical social movement scholars (Guthman 2007, Holifield, 2004) make few observations about how Polanyian theory might better capture complex varieties of mobilization. But recent research begins to capture pro-neoliberal activism. Noteworthy examples include Malin (2014, 2015), who identifies and analyzes environmental justice sites of accdeptance and resistance; in sites of acceptance, industrial modes of production and their risks are supported by grassroots activists. Harrison (2014) notes the importance of different "notions of environmental justice" present across US communities and institutions. Bell (2016) analyzes the challenges present in micromobilization for environmental justice in the context of Appalachian coal production. Jerolmack and Walker (2018) note similar patterns, which they term "quiet mobilization" amid Appalachian hydraulic fracturing. Additionally, McCarthy (2005b) finds, distinctly, that U.S. community forestry sites can act as "hybrids between neoliberalism and...natural resource management" (995) - even though his other research shows rural cooperative can act as common spaces that counter neoliberalism (2005a). Wilshusen (2010) observes communities in southeastern Mexico that have adapted to free market logic in agricultural settings. Valdivia (2005) showcases interactions between identities and neoliberalization processes in Ecuador, analyzing how native people's identities shifted to accommodate free market systems. In the U.S., Holifield (2004) concludes that environmental movements may be brought increasingly under the logics of neoliberalism via institutionalized programs like the Environmental Protection Agency. In these cases, activists serve to institutionalize rather than challenge neoliberalism. Finally, Block and Somers (2014) display the power of market fundamentalism in U.S. narratives, as neoliberalism maps fluidly on to historical American ideals like individualism, liberty, and private property rights. They provide exceptional insight into market fundamentalism, but stop short of analyzing structural factors that normalize U.S. market fundamentalism. Yet, few scholars utilize double movement theory critically, or empirically test Polanyian double movement propositions in neoliberalized contexts - and this narrow view tends to privilege research that does not focus on these divergent cases. A deeper understanding is needed regarding how cultural narratives are historically shaped by structural mechanisms. As Dale (2010) observes, "writers...have not paid sufficient attention to the problem that many so-called counter-movements...have themselves been energetic agents of marketization and commodification" (2010:220). There is a need to theorize the ways that the double movement accommodates neoliberalizing structural contexts that help normalize neoliberalism in cultural contexts. While Polanyi's double movement theory accounts for regressive activism, it must be used more creatively and critically. Because something new is mobilizing. So far, though, scholarly analyses don't systematically analyze activism that supports what Polanyi predicted grassroots activists would contest: free market systems, the de-regulation and re-regulation that enables corporations to self-monitor, and reduced environmental protections. We need more systematic analyses of pro-neoliberal activism where activists identify 
with market-based systems, express faith in free trade (Bourdieu 1998), and trust corporations to self-regulate. Where activists have developed deep neoliberal subjectivities. Pro-neoliberal activism represents more than an extension of laissez-faire capitalism. Instead, grassroots activists (not astroturf guns-for-hire) or related organizations mobilize 'sites of acceptance' and 'triple movements' (Malin, 2014, 2015), where deregulation, marketization, and commodification of public goods are accepted, even lauded. Pro-neoliberal activism embodies neoliberal norms that elevate individuals, privilege individual-level achievements, and characterize individuals as main drivers of social change through their power as consumers, not citizens (Bourdieu 1998; Harvey, 2005; Mudge, 2008; Castree, 2010). Neoliberalized cultures idealize self-sufficient individuals. Thus, millions of people experience powerful pressures to prioritise their own economic needs above society or environment, as public social safety nets diminish. Our work addresses this gap, through exploration of the pro-neoliberal activism forming sites of acceptance in uranium communities. We offer observations of pro-neoliberal activism that mobilizes at the grassroots, that is community-based (i.e., not elite), and yet actively supports neoliberal mechanisms of development, particularly: free, self-regulating markets, de- and re-reregulation, and commodification of fictitious commodities such as land and money.

\section{A case for consideration: pro-neoliberal activism in paradox Valley, Colorado}

In January 2011, Energy Fuels Resources, Inc. received a special-use permit and radioactive materials license to build Piñon Ridge Uranium Mill (PR Mill), deep in southwestern Colorado's Paradox Valley. Nestled in the West End of Montrose County, the proposed site comprises about 880 acres situated along Highway 90. The area's major land uses include agriculture, recreational opportunities on a wide variety of public lands, and mining (CDPH\&E EIA 2011). Until the Montrose County Commission rezoned the mill site - privately owned by Energy Fuels - it had been grazing land. A few houses and farms dot the rural landscape, but the mill facility ${ }^{2}$ would be constructed away from major population centers. Importantly, in 2017, the permit for the mill was sold by Energy Fuels after being challenged in federal court on the grounds that the permitting agency neglected to adequately consider socio-environmental risks. Two rural communities are closest to the proposed location. Nucla, Colorado, has 732 residents, a poverty rate of about $24 \%$ (US Census 2009), and a tradition of skepticism regarding capitalism. The town's 1893 charter asserted that market-oriented competition "makes it almost impossible for an honest man or woman to make a living, and the cooperative system, if carried out properly, will give the best opportunity to develop all that is good and noble in humanity." Naturita, Colorado, Nucla's sister city located just four miles away, has 635 residents and a poverty rate of about 14\% (US Census 2009). Both communities have legacies of uranium production, coal mining, agriculture, and other natural resource-based industries. Uranium's regional legacies include disruptive boom-bust cycles, contested illnesses and cancer clusters related to uranium exposure, and defiled landscapes where thousands of abandoned, radioactive mine shafts and mill tailings piles still dot the Four Corners region (Malin 2010; Malin, 2015). The industry's reputation and its renewal are contested. The Piñon Ridge Uranium Mill was the first U.S. uranium mill permitted since the 1980s, and has reinvigorated long-standing debates over uranium's legacies. Some groups resist renewed uranium production, fostered by free markets and privatized investment (Malin, 2015). Other groups, which are the focus here, represent qualitatively different kinds of

\footnotetext{
${ }^{2}$ Plans for the facility include the 17 -acre uranium mill, a variety of tailings ponds totaling about 90 acres, a building for office and administrative duties, an evaporation pond that will be about 40 acres, access roads, and a storage pad for the ore covering about six acres.
}

mobilization - pro-neoliberal activism - where activists support uranium production's renewal, and prioritize local control over land use as a key socio-environmental justice issue. Pro-neoliberal activists in this context possess strong historical identification with uranium and have faith in private companies to responsibly self-regulate while creating local employment, despite chronic recession related to the uranium market's collapse in the early 1980s. Local identification with uranium markets provides a main driver behind mobilized support for renewed local uranium production and global nuclear markets; supporters believe revived uranium markets will reinvigorate local community, quality of life, and perceptions of self-sufficiency. Importantly, supporters also trusted companies such as Energy Fuels to self-monitor their regulatory compliance.

\subsection{Uranium's neoliberalization, marketization, \& privatization}

Prior to World War II, uranium had no market value. It was discarded as refuse from which more valuable commodities such as radium or vanadium were extracted (Ringholz, 2002). This changed in the 1930 s, as the U.S. Department of Defense became interested in uranium's potential role in atomic warfare. The U.S government encouraged prospectors to search for uranium scattered around the Colorado Plateau, creating such frenzy that some compared the first uranium boom to the California Gold Rush (Amundson, 2002). The rush created a booming market for uranium. The U.S. uranium industry has shifted alongside the American political economy. Four mechanisms of (neo) liberalization shaped the industry, and, likewise, public response and mobilization. Policies related to uranium markets were early harbingers of the U.S. turn to neoliberalism, enacting key mechanisms marketization, privatization, state reregulation, and regulatory devolution - before neoliberalism became hegemonic in the U.S. These mechanisms shaped the industry while creating conditions favorable to pro-neoliberal activism supporting renewed U.S. uranium production. Four Corners communities powered the U.S. through the Cold War, despite weathering disruptive uranium booms and busts (Malin, 2015; Zoellner 2011; Ringholz, 2002). Nuclear weapon development and Cold War stockpiling created an unprecedented and state-supported boom from the mid-1940s to the early 1960s. Nucla and Naturita's populations grew from 1200 people in 1930 to about 5500 residents by 1960 (Hessler, 2010, 2011; Power, 2011). But uranium supplies were soon saturated, and by the mid-1950s the US government decided to loosen its grip on uranium production. In 1954, the Atomic Energy Act of 1946 was amended to allow private investment in uranium, mostly to spur a commercial atomic energy industry to provide power (Malin, 2015). Naturita's uranium mill was closed by 1963. Despite a small increase in uranium activity in the 1970s, the 1980s marked a chronic bust period in uranium markets (Power, 2011) that lasted until the mid-2000s. High-profile accidents including Three Mile Island and the meltdown at Chernobyl led to public ambivalence regarding nuclear power and depressed uranium prices until about 2007. Today - with nuclear power championed as a climate-friendly, low-carbon energy option- uranium prices are higher and have led to renewed U.S. production. This phenomenon has grown since 2016, due to recent nostalgia for inwardlooking approaches towards domestic production by President Trump.

\subsection{Uranium industry re-regulation and devolution of governance}

The uranium industry's marketization, subsequent privatization, and even its boom-bust cycles sparked shifts in governance that changed approaches to industrial regulation. The 1954 Atomic Energy Act also changed the responsible parties overseeing regulatory compliance, creating more opportunities for private and commercial investment (Amundson, 2002). Importantly, this marked a significant move toward privatizing the industry, as the U.S. government had been the only legal purchaser of uranium in the U.S. until that point, having a monopsony over uranium markets (Malin, 2015). This new industry 
structure also demanded new regulations. The Act substantially reregulated the uranium industry and structured devolution in industry governance. The Act created a system of Agreement States, whereby individual states could lobby the federal government to acquire sole zoning and regulatory control over uranium and nuclear-related production in their states (Malin, 2015). If the state, for example Colorado, could establish that its own state-level regulations were as strict or stricter than federal regulations, regulatory control and monitoring would be devolved to that state. Importantly, the industry must also comply with another suite of federal regulations that have been promulgated in recent decades. If mining is done on federal land, the National Environmental Protection Act (NEPA) must be followed, and federal Clean Air Act standards apply to radon emissions. Further, the Mine Safety and Health Act established oversights for worker safety in uranium mines by putting caps on the number of working man hours [sic] they could spend underground and exposed to radon daughters and other environmental risks. The Uranium Mining Tailings Radiation Control Act (UMTRCA) was also passed in 1978, which provided for the federal remediation and environmentally sound securement of tailings waste left at numerous Department of Energy (DOE) sites around the U.S. (DOE 2016). While these advancements were important and marked progress, albeit delayed, there are concerns that the lack of coordination among agencies and multiple levels of government means that no one monitors the cumulative impacts of uranium production (Malin, 2015). Regarding industry's structural changes, the Energy Reorganization Act of 1974 further devolved industry control by splitting governance functions carried out by the Atomic Energy Commission into two branches. The Department of Energy now promotes nuclear power and technological development; the Nuclear Regulatory Commission now oversees most federal nuclear regulations, including Agreement State designation and compliance. Currently, 37 states are designated Agreement States, and they self-monitor their regulatory compliance using state-specific policy infrastructures. While this devolution has its drawbacks, it does allow for state regulators to utilize their more site-specific knowledge about industrial and environmental risks and outcomes. With regulatory oversight split at federal level and with many Agreement States regulating their own compliance in relation to uranium and nuclear technologies, regulation of the U.S. uranium industry has become more scattered, with little unification in terms of approaches, standards, or institutions regulating the industry. Conversely, U.S. uranium production has become unified, as Energy Fuels Resources became the largest uranium operator in the U.S. (Malin, 2015). Amid reduced federal and state budgets since 2008, it has become increasingly difficult for states to fulfill their duties as Agreement States, with decreased funding to support increased regulatory and enforcement duties. Individual states must budget for this type of enforcement, and each state has its own approach. In Colorado, the Colorado Department of Public Health and Environment has a Radiation Management Unit that oversees all uranium-related activity (minus air pollution) in the state. However, because their budget has been substantially reduced due to anti-taxation legislation and reduced funding for public institutions (Malin, 2015), companies such as Energy Fuels operating in Colorado, often monitor their own regulatory compliance and report to state regulators.

\section{Pro-Neoliberal energy activism in Southern Colorado}

Today, persistent poverty colors daily life in uranium communities like Nucla and Naturita, where residents feel keen economic dislocation (Malin, 2015, 2014). Few economic opportunities exist, though a fledgling hemp cultivation industry has been created by local entrepreneurs. Most jobs involve unstable, low-wage service-based employment in tourism communities like Telluride, and persistent unemployment has plagued residents since uranium markets last busted in the early 1980s. The two towns recently closed their middle school and moved all students to one building, due to declining enrollment numbers, and the school recently moved to a four-day schedule to cut expenses (Hessler, 2010, 2011). Life has long been challenging in isolated uranium communities like these, characterized by poverty, spatial isolation and natural resource dependence (Malin, 2015). Community activists mobilizing support for Piñon Ridge Mill construction see revitalized uranium production as a chance for secure, place-based rural livelihoods - as a salve for social dislocation related to their persistent poverty and, ironically, their historical natural resource dependence. Activists see the mill as a mechanism to rebuild their communities, with its potential to generate economic revitalization, leading to improved infrastructure, schools, and new local businesses catering to medical, entertainment and shopping needs. Currently, most Paradox Valley residents express strong support for the Mill specifically and for privatization, renewed marketization, and even devolved regulation of the uranium industry more generally. For example, $78 \%$ of those surveyed in the four communities closest to the proposed mill site strongly support its construction. Some of the most vocal activists are local political leaders and business owners, but active support cuts across socio-economic classes, age groups, occupations, and genders. Pro-neoliberal activists emphasized a few specific arguments: people in uranium communities have greater familiarity with uranium than most US populations; they trusted companies like Energy Fuels to be environmentally responsible, adhere to regulations, and oversee their own regulatory compliance; and they saw renewed uranium production as an environmental justice issue related to community control over land use decision-making (Malin, 2014). Uranium's legacy in Paradox Valley intersects with environmental justice and health impacts related to midcentury uranium production (Ringholz, 2002; Brugge and Buchner, 2011). In 1986, Uravan, a former Union Carbide company town, was declared a Superfund site and the 600-person population was relocated to surrounding communities, including Nucla and Naturita. Uravan's 260 structures were razed to the ground, and there is an on-going class action lawsuit brought against Union Carbide by former employees and residents for illnesses including cancers, and respiratory and reproductive disorders. Yet, mobilized mill supporters give little credibility to claims of negative health impacts, empowered by a recent epidemiological study commissioned by Union Carbide (Boice et al., 2007), which found no statistically significant levels of increased cancer among Uravan millers or community members, though elevated rates of lung cancer were found among former miners. Importantly, this study had a poor epidemiologic design and was otherwise flawed (Malin, 2015), yet it influenced public opinion about the mill in the region. In many interviews, almost all uranium industry supporters cited this study to deny claims of negative health impacts. Advocates of the corporate-funded study include the region's only pharmacist, a highly influential community member and outspoken activist (Malin, 2014; Hessler, 2011). These represent important examples of contested illnesses (Brown, 2007), wherein people link environmental exposures to illness even when those observations are contested by state other agencies (Malin, 2010).

\subsection{Conditions nurturing pro-neoliberal activism: community identification with uranium markets}

Residents of uranium communities like Nucla, Naturita, and Uravan long for childhoods spent at the company store, school, or swimming pool. In interviews with residents, they often tied these fond memories to uranium itself. Hundreds of uranium community residents, mobilized activists, uranium miners, and millers attend the annual Uravan Survivors Picnic, held each spring on the grounds of Uravan. NuclaNaturita's Rimrocker Historical Society has developed uranium-centered tourism retreats, tying their community fabrics even more tightly to the industry. The local newspaper, the San Miguel Basin Forum, displays uranium's current market prices in the top right corner of every weekly issue. These indices are accompanied by frequent front-page stories covering regional uranium market expansion. Driving down 
Naturita's Main Street, you cannot miss the twenty-foot-tall, green, refurbished Uranium Drive-In sign that proclaims 'Without unity, there is no community,' leaving little question that most community members see uranium as central to their community's social fabric and history. If you choose not to support the industry's renewal, then you are perceived as an outsider who misunderstands the community and its historical connection to uranium. Activists at public meetings identify themselves as "fourth generation" residents and as uranium workers, alluding to their family's multi-generational settlement in the region and familiarity with mining and milling (Hessler, 2011; Malin, 2015). Pleas to return to the "Union Carbide Days" or "Uravan Days" (Hessler, 2011; Malin, 2015) have been made at public meetings, comment sessions, and in the first author's interviews with many community members. Results from the survey distributed in four uranium communities closest to the proposed Piñon Ridge Mill display this strong identification with the uranium industry across genders and ages. In a quotation that represents a consistent theme from interviewees and survey respondents, one individual explained her connection to uranium and support of the mill: "I have lived in the Uranium Belt most of my life. My father was a miner and my husband worked for Union Carbide. This is a good life we have here, and we are not afraid of uranium. I have eaten buckskin that was hung in the mines to cool and washed myself in water pumped out of these mines, and I guarantee I don't glow in the dark...We are not rich people. All we ask is to make a good living we can trust." Said another female Nucla resident: "I think it [uranium production] is our identity. I think it's our history. It's who we are." Another mill supporter from Naturita explained his community's identification with uranium: "The only reason these areas were settled in the first place was because of uranium and vanadium. So these people's histories, our heritage, our families, our everything - at some point they are strongly tied to uranium." Uranium legitimized their communities, the historical role of uranium there, and the community's contemporary relevance on the global stage. Said one interviewee, "I hear people say we need the jobs, and it makes me so angry...because the country needs us as much or more than we need the jobs. We're one of the few places that would ever consent to do this...But we're willing to do this because nuclear power...is the only thing that's going to solve this country's problems.

\subsection{Conditions nurturing pro-neoliberal activism: trust in corporate self- regulation}

Private corporations have been the primary drivers of renewed growth in North American uranium markets. Energy Fuels, a Torontobased uranium and vanadium resource firm, owned Piñon Ridge Mill's proposed site and related building permits at the time of heightened public concern, and during major data collection in 2010-2011. Due to recent mergers and acquisitions, Energy Fuels has positioned itself as the single largest producer of uranium in the US, after merging with Denison Mines in 2013 (Malin, 2015). Despite its Canadian pedigree and initial public stock offerings, Energy Fuels focuses its production activities in the US, on the uranium-rich Colorado Plateau in the sparse Four Corners region. Energy Fuels frames itself as "a local company with strong ties to Colorado and Western Montrose County" (EF Information Session 2010). Since the early 1980s, Colorado native and former company CEO George Glasier has called a ranch near Nucla home, and he is trusted as a 'local' by mobilized mill supporters. Energy Fuels has offices in Nucla and Lakewood, Colorado, and Kanab, Utah, and the company highlights that most of their management team is comprised of "long-time Colorado residents" (EF Information Session 2010). Energy Fuels promises that it would never endanger its neighbors, and to construct the "most technologically advanced and environmentally friendly uranium mill in existence" (EF Information Session 2010). When Energy Fuels sold the permit to George Glasier's investment firm, Baobab Investments LLC, the mill's future remained in private hands, trusted by the community. Given Colorado's status as an
Agreement State, the federal government no longer regulates uranium production, which falls to the Colorado Department of Public Health and Environment (CDPH\&E). Yet, the state's reduced budget and personnel mean that Energy Fuels will be relied upon to self-monitor their regulatory adherence to environment and occupational rules. Energy Fuels' reputation as a local institution establishes the corporation as a trusted, integral part of community social fabrics, where uranium has a powerful, if romanticized, presence. In the first author's interviews, and throughout survey responses, people mobilizing support for the mill expressed trust in Energy Fuels to self-monitor its regulatory compliance, mostly because interviewees trusted that company leaders cared about local residents. Said one Nucla resident: "The first [public] meeting I went to, I was so impressed...There was a presentation by Energy Fuels about all the efforts they are making...to make sure the mill is using the best technology and the most up-to-date information possible to make it safe and efficient...I appreciate that. It seems to me what else can be done? I feel like we're in good hands with Energy Fuels." Trusted community leaders expressed their faith in Energy Fuels and the integrity of the company's leadership, helping motivate mobilization supporting the mill. Said one elected official: "I have gone toeto-toe and face-to-face with them [Energy Fuels management]...and point blank said 'This is a problem and what are you going to do about it?' Never once have they ho-hummed around; they have always come back and given me direct answers immediately...The company and George Glasier have been tremendous." Another life-long resident and elected official made the following observations about the important role public meetings have played in engendering people's trust: "Energy Fuels has been very open. George Glasier presented an awesome presentation recently and another through the Chamber. They [Energy Fuels] had tours on their site that a lot of us went to, and they explained things in detail. I believe that they have been an open book, and try to get the public to understand and know everything...I mean, they have never been secretive."

\subsection{Conditions nurturing pro-neoliberal activism: trust in private transparency \& privileging economic development}

Though pro-neoliberal activism mobilized organically within Paradox Valley uranium communities, Energy Fuels enhanced local support by mounting a transparency campaign during the licensure process and by presenting themselves as a sympathetic economic ally. Energy Fuels held several public meetings and information sessions including community barbecues where residents were welcomed, treated to a free meal and beer, and then encouraged to discuss the mill. The transparency campaign helped establish several avenues through which residents could access thousands of pages of technical reports, socioeconomic reports, and other information on CDPHE and/or Energy Fuel's websites. The company's practice of hiring local people to collect baseline data for CDPHE licensure displayed that the local company understood people's persistent poverty and isolation (Malin, 2015). Energy Fuels' transparency campaign encouraged the pro-neoliberal, pro-mill movement, precisely because their strategies for transparency lent the process an appearance of procedural equity and control over local land use decisions (Lake 1996; Schlosberg 2007). Yet, the thousand-plus pages of highly specialized technical, legal, and economic analyses were made available on-line were not readily useful or transparent to most rural Nucla and Naturita residents, let alone most Americans. Mobilized mill supporters nonetheless felt included by Energy Fuels in the licensure process. Revitalizing the uranium industry and its global markets became their fight, too. Standing on their reputation as a trusted, transparent local institution, Energy Fuels fortified enhanced support for the mill and uranium industry revitalization even more by appealing to the economic vulnerabilities and class status of residents. Energy Fuels rekindled regional class-based tensions, particularly between Paradox Valley residents and people living in wealthier communities where many opposed the mill (like Telluride). 
For example, Energy Fuels' frequent reference to Nucla and Naturita residents not having to 'clean the toilets' of people living in upper-class Telluride helped the company enhance trust further, by showing that the company was on the side of working-class Nucla and Naturita residents. While socio-economic analyses offered drastically different estimations for the number of jobs the mill was likely to create - ranging from 35 to 649 jobs (Power, 2011) - supporters believed the more generous estimates as class tensions flared. The perception of local hiring was strong and helped intensify support. Said one local and elected official: "Energy Fuels is going to hire mostly locals. The morals and ethics of the people in this area, are very strong for the most part...They are not going to see anything go wrong. I mean, they are going to be there for their fellow worker, for the company.... f feel very comfortable things will be monitored well." Pro-neoliberal activists now dominate local space for democratic discussion about the Mill. Mobilized Mill support has become so dominant regionally that it extinguishes concerns expressed by other people. Concerns about environmental, health, and regulatory outcomes have been able to flourish only in extralocal spaces (Malin, 2015). For example, several Nulca and Naturita residents spoke off-the-record about their opposition to the Mill and their lack of involvement in mobilized support. They felt unwilling to share these sentiments publicly, for fear that opposition might negatively affect their long-term relationships, community standing, or their own businesses. Local opponents who were vocally opposed have now largely fallen silent, claiming they received death threats from local Mill supporters. In several interviews and more survey responses, residents opposed to the mill expressed feeling intimidated about voicing their concerns about PR Mill's construction. Importantly, these were not representative of the majority of community residents, as reviewed survey results support, but these experiences highlight important power held by the industry. Support for renewed uranium activity dominates the area, perhaps encouraging a unique and neoliberalized form of activism.

\section{Discussion and conclusions: the ironies of pro-neoliberal activism}

\subsection{Theoretical lessons}

Polanyi's framework offers the tools to understand why people might mobilize differently under neoliberal capitalism than under other varieties of capitalism. In neoliberalized political contexts, residents of uranium communities like Nucla and Naturita must alleviate their most pressing sources of social dislocation - poverty and spatial isolation before attending to other disruptions. Desperate, persistent poverty often trumps longer-term concerns about environmental degradation. Hunger and possible homelessness are more immediate considerations than eventual cancer diagnoses. Polanyian theory must be more critically and creatively applied under neoliberal hegemony, where even activists celebrate privileging free markets, privatization, and deregulation. Scholars must systematically address the questions we ask here: 1) How does pro-neoliberal activism contribute to the embedding and further institutionalization of neo-liberal regimes? 2) What structural mechanisms precede and help facilitate grassroots support for free markets and corporate self-regulation, as opposed to support for reembedding markets in local, public social protections? Using evidence from uranium communities, we show how pro-neoliberal activism further embeds and deeply institutionalizes neoliberal policy regimes in the U.S. Historically, four structural mechanisms of neoliberalization marketization, privatization, de-regulation, and market-friendly reregulation - helped expand and empower the American uranium industry. Today, these mechanisms continue to create conditions favorable to pro-neoliberal activism in communities like Nucla and Naturita, which aims to embed communities in globalized energy markets, privatized resource regimes, and corporatized systems of self-regulation, rather than re-embedding those markets into community social fabrics.
Conditions nurturing pro-neoliberal activism -1) identification with the uranium industry; 2) trust in uranium corporations to self-regulate; and 3) trust in corporations like Energy Fuels Resources - map on to the four mechanisms that neoliberalized the uranium industry. People's identification with the industry connects with the marketization of uranium that began in the 1940s and continues today. Uranium's marketization gave it incredible economic and cultural value. It also put U.S. uranium communities on the map, transforming them from invisible outposts into central nodes in the race to beat the Soviets. Residents saw their participation in the uranium industry as patriotic duty during WWII and the Cold War. Today, pro-neoliberal activists supporting uranium characterize nuclear energy as a patriotic means of breaking free from dependence on foreign oil and contributing to climate change mitigation. Residents' identification with uranium has continued over time, intensifying even as the 1980s uranium bust became a chronic recession. People see uranium markets as familiar parts of their community's social fabrics, which makes them more likely to mobilize support that will deeply institutionalize and further embed the industry. In subsequent decades, the uranium industry's privatization and deregulation mapped on to public trust in corporations like Energy Fuels Resources. Residents' trust in corporate self-regulation, where industry actors monitor their regulatory performance, has been a central condition nurturing pro-neoliberal activism. The privatized uranium industry offer supporters perceived stability because of its separation from the federal government, which people see as centrally responsible for environmental injustices tied to previous uranium booms (Ringholz, 2002; Malin, 2010). While the industry has had problems before, activists say current private industry operators like Energy Fuels will perform differently. Finally, market-friendly re-regulation helped legitimate corporate governance, encouraging pro-neoliberal activism and normalizing neoliberalism in these spaces. States like Colorado monitor the uranium industry's regulatory compliance, but also turn that responsibility over to corporations due to budgetary constraints. Companies are trusted to report their own regulatory missteps. But proneoliberal activists the first author interviewed trust in corporate selfregulation, transparency, and the private sector's ability to create local employment. Instead of asserting a need for independently administered social protections or regulations enforced by a third party, mill supporters mobilize distinctly market-privileging activism, though selfmonitoring is widely questioned by environmental justice advocates (e.g., Mohai et al., 2009). Yet, pro-neoliberal activists mobilize because they want to encourage devolved governance and see it as a positive outcome. In neoliberal contexts, market-based ideologies become normalized and encourage individualization of most aspects of daily life. In isolated and impoverished places like uranium communities, people cope with neoliberalism's de-humanizing outcomes through their strong identification with markets and their trust that companies developing those markets locally will perform safely while simultaneously securing residents' rural livelihoods. But what do these pro-neoliberal assumptions really mean for social activism, community development, and progressive social change?

\subsection{Theoretical and empirical significance}

The nature and tactics of activism change in contexts where community members identify strongly with a given industry or market, even if those markets are disembedded from social protections. In essence, neoliberal market logics begin to inform social movement logics - activists' mobilization, goals, and membership. Instead of rejecting disembedded markets, pro-neoliberal activists fight for market expansion and normalize the dominance of disembedded, free markets. What this means for the nature of social change, and for the transformational capacity of social activism in the U.S., remains an empirical question that should be explored further. The case presented here suggests that pro-neoliberal activism, which often targets corporations and sees them as primary governing institutions, serves to embed and institutionalize 
neoliberal regimes. It does not, however, seem to encourage transformative social change or target the state for comprehensive regulatory standards. Quite the opposite. Instead, pro-neoliberal activism links tightly to formation of neoliberal subjectivities (Guthman, 2008), layering its power to embed and deeply institutionalize neoliberal regimes. Identification with uranium markets and denial of uranium's problematic environmental health legacies interact in powerful ways with narratives of self-sufficiency and 'remoralization of the poor' (Castree, 2010). Pro-neoliberal activism thrives in these contexts because it helps people's sense of the collective (Bourdieu, 1999); as in uranium communities, they can collectively mobilize around the market - but for deeply individualized reasons. American citizens have internalized the notion that they are solely responsible for their own socio-economic failures and have individualized all responsibility, rather than seeing structural factors as equally important in their quality of life. Uranium's historical connection to communities and people's individualized identities as uranium miners or millers strengthen these more general American cultural frameworks and help facilitate proneoliberal activism - even when supporters have to ignore historical boom-and-bust economic instability, socio-environmental legacies, and deep power imbalances. In its privatized form, the structure of the contemporary uranium industry is just different enough to facilitate (localized) public trust, despite its problematic past. When Energy Fuels promised self-monitored safety and abundant employment, that corporation began to act as a proxy for the state. Not just in its regulatory self-monitoring, but in its potential provision of social safety nets. Residents believe the uranium industry will bring economic security, health insurance, and, importantly, a sense of pride in having respectable, familiar employment. Pro-neoliberal activism mobilizes not simply to encourage market growth, but because residents feel that employment in the uranium industry provides an especially valuable and respectable means to alleviate social dislocation. Neoliberal narratives of self-sufficiency interact with local identification with the industry to create powerful foundations for pro-neoliberal activism. Neoliberalism's hegemonic power and resonance with American ideals (Harvey, 2005) make this new narrative difficult to resist. As neoliberal policies constrain states to privatize natural resources and public goods, de- and re-regulate, and shrink social support systems, rural communities must make development decisions in a constrained manner. Our findings suggest that communities embedded in neoliberalized contexts, especially those dependent upon natural resources, may be constrained to choose the 'lesser of two evils'. They are forced to ask: 'Poverty now, or cancer thirty years later?' Pro-neoliberal activism may thus do little to transform approaches to economic development that have proven unsustainable and risky, ultimately doing little to repair community social fabrics or enhance quality of life. In a context where people cannot meaningfully choose between their livelihoods and healthy environments and bodies, we see symptoms of structural violence and environmental injustice (Farmer, 2004). Rather than striving to repair local social fabrics collectively or utilize non-economic means to enact transformative social change, pro-neoliberal activists retrench into now-familiar, individualizing neoliberal regimes and policy discourses. This instance of pro-neoliberal activism is one symptom of a bigger societal shift toward activism that is not simply regressive, as Polanyi might write, but is fundamentally different in the ways people may privilege corporations, free markets, corporate self-regulation, and individualized concerns over social protections and even collective community social fabrics. Seemingly disparate instances of social mobilization reflect the increased occurrence of pro-neoliberal activism from organized public support for Donald Trump, to community-wide support of coal corporations in West Virginia's rural coal towns (Bell, 2016), support for unconventional oil and gas production, and arguments that federal lands should be returned to western states. These are just a few examples that reflect a societal shift to pro-neoliberal activism in the U.S. - one that needs to be more rigorously interrogated across economic sectors, regions, and national contexts.

\section{References}

Adaman, Fikret, Devine, Pat, Ozkaynak, Begum, 2003. "Reinstituting the economic process: (Re)embedding the economy in society and nature.”. Int. Rev. Sociol. 13 (2), 357-374.

Amundson, Michael A., 2002. Yellowcake Towns: Uranium Mining Communities in the American West. University Press of Colorado, Boulder, Colorado.

Bakker, Karen, 2003. An Uncooperative Commodity: Privatizing Water in England and Wales. Oxford University Press, Oxford.

Bakker, Karen, 2010. Privatizing Water: Governance Failure and the World's Urban Water Crisis. Cornell University Press, Ithaca, N.Y.

Bell, Shannon Elizabeth, 2016. Fighting king coal: The challenges to micromobilization in Central Appalachia. MIT Press.

Block, Fred, 2008. "Polanyi's Double Movement and the Reconstruction of Critical Theory.” Revue Interventions Économiques 38 Accessed August 22, 2014. http:// interventionseconomiques.revues.org/274.

Block, Fred, Somers, Margaret R., 2014. The Power of Market Fundamentalism. Harvard University Press, Cambridge, MA.

Boice, John D., Cohen, Sarah S., Mumma, Michael T., Chadda, Bandana, Blot, William J., 2007. "Mortality among residents of Uravan, Colorado, who lived near a Uranium Mill, 1936-84.”. J. Radiol. Prot. 27 (3), 299.

Bourdieu, Pierre, 1999. "Neo-liberalism, the utopia (becoming a reality) of unlimited exploitation.". Acts of Resistance: Against the Tyranny of the Market. The New Press, New York, pp. 94-105.

Brown, Sandy, Getz, Christy, 2008. "Privatizing Farm worker justice: regulating labor through voluntary certification and labeling.". Geoforum 39 (3), 1184-1196.

Brugge, Doug, Buchner, Virginia, 2011. Health effects of uranium: new research findings. Rev. Environ. Health 26 (4), 231-249.

Bugra, Ayse, Agartan, Kaan, 2007. Reading Karl Polanyi for the twenty-first century: market economy as a political project. Springer.

Bury, Jeffrey, 2004. Livelihoods in transition: transnational Gold mining operations and local change in Cajamarca, Peru.". Geogr. J. 170 (1), 78-91.

Castree, Noel, 2008a. Neoliberalising nature: the logics of deregulation and reregulation. Environ. Plann. A40 (1), 131.

Castree, Noel, 2008b. Neoliberalising nature: processes, effects, and evaluations. Environ. Plann. A40, 153.

Castree, Noel, 2010. Neoliberalism and the biophysical environment 2: theorising the neoliberalisation of nature. Geogr. Compass 4 (12), 1734-1746.

Cox, Robert W., 1994. The crisis in world order and the challenge to International organization. Coop. Conflict 29 (2), 99-113.

Dale, Gareth, 2010. Social democracy, embeddedness, and decommodification: on the conceptual innovations and intellectual affiliations of Karl Polanyi. New Polit. Econ. 15 (3), 369-393.

Dale, Gareth, 2012. Double movements and pendular forces: Polanyian perspectives on the neoliberal age. Curr. Sociol. 60, 3-27.

Farmer, Paul E., 2004. Pathologies of Power: Health, Human Rights, and the New War on the Poor, 2nd ed. University of California Press, Berkeley.

Fletcher, Robert, 2010. Neoliberal environmentality: towards a poststructuralist political ecology of the conservation debate. Conserv. Soc. 8 (3), 171-181.

Foucault, Michel, 2008. The birth of biopolitics: lectures at the collège de France, 1978-79. In: Senellart, Michel (Ed.), Translated by Graham Burchell. Houndmills, U.K. Palgrave Macmillan.

Fraser, N., 2017. From progressive neoliberalism to trump-and beyond. Am. Aff. 1 (4), 46-64.

Gauchat, G., 2012. Politicization of science in the public sphere: a study of public trust in the United States, 1974 to 2010. Am. Sociol. Rev. 77 (2), 167-187.

Guthman, Julie, 2008. Neoliberalism and the making of food politics in California. Geoforum 39 (3), 1171-1183.

Harrison, Jill Lindsey, 2014. Neoliberal environmental justice: mainstream ideas of justice in political conflict over agricultural pesticides in the United States. Environ. Politics 23 (4), 650-669.

Harvey, David, 2005. A Brief History of Neoliberalism. Oxford University Press, Oxford. Hejeebu, Santhi, McCloskey, Deirdre, 1999. The Reproving of Karl Polanyi. Crit. Rev. 13 (3-4), 285-314.

Hessler, Peter, 2010. The Uranium Widows." New Yorker. September 13,.

Hessler, Peter, 2011. "Dr. Don." New Yorker. September 26. . http://www.newyorker. com/reporting/2011/09/26/110926fa_fact_hessler? currentPage $=$ a.

Hettne, Björn., 1991. Security and peace in Post-Cold war Europe. J. Peace Res. 28 (3), 279-294.

Heynen, Nik, McCarthy, James, Prudham, Scott, Robbins, Paul, 2007. Introduction: false promises. Neoliberal Environments. Routledge, pp. 13-34.

Heynen, Nik, Perkins, Harold A., 2005. Scalar dialectics in Green: Urban private property and the contradictions of the neoliberalization of nature. Capitalism Nat. Socialism 16 (1), 99-113.

Heynen, Nik, Robbins, Paul, 2005. The neoliberalization of nature: governance, privatization, enclosure, and valuation. Capitalism Nat. Socialism 16 (1), 5-8.

Holifield, Ryan, 2004. Neoliberalism and environmental justice in the United States environmental protection agency: translating policy into managerial practice in hazardous waste remediation. Geoforum 35 (3), 285-297.

Jerolmack, Colin, Walker, Edward T., 2018. Please in My Backyard: Quiet Mobilization in Support of Fracking in an Appalachian Community. American J. Sociol. 124 (2), 479-516.

Katz, M.B., 1989. The Undeserving Poor: From the War on Poverty to the War on Welfare, vol. 60. Pantheon Books, New York, pp. 173-187.

Konings, M., 2012. Neoliberalism \& the State. Alternate routes. J. Crit. Soc. Res. 23. 
Malin, Stephanie, 2014. When Is 'Yes to the Mill' Environmental Justice?: Interrogating Sites of Acceptance in Response to Energy Development. Anal. Kritik 36 (2), 263-286.

Malin, Stephanie A., 2015. The price of nuclear power: uranium communities and environmental justice. Rutgers University Press.

Mansfield, Becky, 2007. Privatization: property and the remaking of Nature-Society relations.". Antipode 39 (3), 393-405.

McCarthy, James, 2005a. Commons As counterhegemonic projects. Capitalism Nat. Socialism 16 (1), 9-24.

McCarthy, James, 2005b. Devolution in the woods: Community Forestry As hybrid neoliberalism. Environ. Plann. A37 (6), 995-1014.

Mohai, Paul, Pellow, David, Roberts, J. Timmons, 2009. Environmental justice. Ann. Rev. Environ. t Res. 34, 405-430.

Peck, Jamie, 2013. Explaining (with) neoliberalism. Territory Politics Governance 1 (2), 132-157.

Peck, Jamie, Tickell, Adam, 2002. Neoliberalizing space. Antipode 34 (3), 380-404.

Polanyi, Karl, 1944. The Great Transformation: The Political and Economic Origins of Our Time. Boston: Beacon.

Power, T., 2011. A Socioeconomic Analysis of the Impact of the Proposed Piñon Ridge Uranium Mill Project on Western Mesa, Montrose, and San Miguel Counties, Colorado. Power Consulting, January. .

Prudham, Scott, 2004. Poisoning the Well: neoliberalism and the contamination of municipal Water in Walkerton, Ontario. Geoforum 35 (3), 343-359.
Randles, Sally, 2007. Issues for a Neo-polanyian research agenda in economic sociology. In: Harvey, Mark, Ramlogan, Ronnie, Randles, Sally (Eds.), Karl Polanyi: New Perspectives on the Place of the Economy in Society. Manchester University Press, Manchester, U.K, pp. 409-434.

Ringholz, Raye, 2002. Uranium Frenzy: Saga of the Nuclear West. Utah State University Press, Logan.

Silver, Beverly J., Arrighi, Giovanni, 2003. Polanyi's "double movement": The belle époques of British and US hegemony compared. Politics Soc. 31 (2), 325-355.

Smith, Neil, 2008. Uneven Development: Nature, Capital, and the Production of Space. University of Georgia Press, Athens.

Stanfield, J.Ron, 1986. The Economic Thought of Karl Polanyi: Lives and Livelihood. Macmillan, London.

Tarrow, Sidney, 2005. The dualities of transnational contention: "two activist solitudes" or a new world altogether? Mobilization: Int. Quart. 10 (1), 53-72.

US Government, 2017. Presidential Executive Order Addressing Trade Agreement Violations and Abuses. April 29 $9^{\text {th }}$ 2017. https://www.whitehouse.gov/presidentialactions/presidential-executive-order-addressing-trade-agreement-violations-abuses/.

Valdivia, Gabriela, 2005. On indigeneity, change, and representation in the northeastern Ecuadorian amazon.". Environ. Plann. A37 (2), 285-303.

Watkins, Josh, 2015. Spatial imaginaries research in geography: synergies, tensions, and new directions. Geogr. Compass 9 (9), 508-522.

Wilshusen, Peter R., 2010. The receiving end of reform: everyday responses to neoliberalisation in southeastern Mexico. Antipode 42 (3), 767-799. 